ISSN: 1858-3385, EISSN: 2549-7006

GASTER Vol. 17 No. 2 Agustus 2019

\title{
Pelaksanaan Kelas Ibu Hamil sebagai Upaya Menurunkan Angka Kematian Ibu Studi Lapangan di Puskesmas Plupuh I Sragen
}

\author{
Kamidah, Enny Yuliaswati \\ Program Studi Diploma III STIKES ‘Aisyiyah Surakarta \\ kamidah1975@gmail.com \\ Doi : https://doi.org/10.30787/gaster.v17i2.419 \\ Received: July 2019 | Revised: July 2019 | Accepted: Agustus 2019
}

\begin{abstract}
ABSTRAK
Latar Belakang: Kelas ibu hamil merupakan program yang langsung menyasar pada ibu hamil yang bertujuan untuk meningkatkan pengetahuan dan wawasan kepada ibu hamil. Selama ini pengetahuan ibu hamil hanya terbatas pada konseling yang diberikan oleh bidan saat periksa saja, sehingga pengetahuan yang diperoleh ibu hamil sangat minimal. Dalam kegiatan kelas ibu hamil diharapakan ibu akan mendapat pengetahuan yang lebih luas karena selain mendapat materi dari petugas kesehatan diharapkan juga akan terjadi interaksi antar sesama ibu hamil, sehingga sesama ibu hamil tersebut akan berbagi pengalaman pengetahuan yang berkaitan dengan kehamilan, persalinan, nifas, KB pasca salin, dan perawatan bayi. Tujuan: Mendiskripsikan pelaksanaan kegiatan pelaksanaan kelas ibu hamil di Puskesmas Plupuh I Sragen. Metode Penelitian:Studi Lapangan (Field Research) atau survey diskriptif. Hasil:Kegiatan kelas ibu hamil di Puskesmas Plupuh I dilaksanakan rutin setiap bulan dengan dana anggara dari APBD non Fisik Kabupaten Sragen. Kegiatan kelas ibu hamil dilaksanakan sejak tahun 2013.Simpulan: Pelaksanaan kelas ibu hamil di Puskesmas Plupuh I sudah cukup baik, semua jajaran dari kepala puskesmas sampai masyarakat ikut terlibat dan dapat dilaksanakan rutin setiap bulan.
\end{abstract}

Kata kunci; AKI, kelas ibu hamil

\section{ABSTRACT}

Background: The class of pregnant women is a program that directly targets pregnant women which aims to increase knowledge and insight to pregnant women. During this time the knowledge of pregnant women is limited to counseling given by midwives when checking, so that the knowledge obtained by pregnant women is very minimal. In the classroom activities expectant mothers are expected to get broader knowledge because in addition to getting material from health workers it is expected that interactions will occur between fellow pregnant women, so that fellow pregnant women will share knowledge experiences related to pregnancy, childbirth, 
postpartum, postpartum post copy, and baby care. Objective: Describe the implementation of the implementation of classes for pregnant women at the Plupuh I Sragen Community Health Center. Research Methods: Field Research or descriptive survey.Results: Class activities of pregnant women at the Public Health Center of Plupuh I are held regularly every month with budget funds from the non-physical budget of Sragen Regency. Pregnancy class activities have been carried out since 2013. Conclusions: The implementation of the class of pregnant women at the Plupuh I Community Health Center is quite good, all levels from the head of the puskesmas to the community are involved and can be carried out regularly every month.

Keywords; AKI, class of pregnant women

\section{PENDAHULUAN}

Berbagai upaya dilakukan oleh pemerintah untuk mewujudkan kesehatan yang optimal bagi masyarakat melalui program pembangunan kesehatan. Program kesehatan di Indonesia diutamakan kepada kelompok rentan, yaitu kelompok ibu hamil, ibu bersalin, ibu nifas, bayi dan perinatal. Angka kesakitan dan angka kematian pada kelompok rentan masih tinggi, hal ini ditandai dengan masih tingginya Angka Kematian Ibu (AKI) dan Angka Kematian Bayi(AKB).

Pemerintah telah lama mengupayakan dengan berbagai cara untuk menurunkan AKI dan AKB dengan program kesehatan yang strategis dan program programyang terus disempurnakan. Program-program tersebut diantaranya adalah menempatkan bidan di setiap desa, program gerakan sayang ibu, program kelompok kesehatan ibu dan anak, program $\mathrm{P} 4 \mathrm{~K}$, program kegiatan kelas ibu hamil dan masih banyak lagi program-program lain yang langsung menyasar pada kesehatan ibu dan anak ataupun program lain yang mendukung terciptanya kesejahteraan bagi ibu dan anak (Dirjen Bina Kesehatan Masyarakat, 2009)

Kelas ibu hamil merupakan program yang langsung menyasar pada ibu hamil yang bertujuan untuk meningkatkan pengetahuan dan wawasan kepada ibu hamil. Selama ini pengetahuan ibu hamil hanya terbatas pada konseling yang diberikan oleh bidan saat periksa saja, sehingga pengetahuan yang diperoleh ibu hamil sangat minimal. Dalam kegiatan kelas ibu hamil diharapakan ibu akan mendapat pengetahuan yang lebih luas karena selain mendapat materi daripetugas kesehatan diharapkan juga akan terjadi interaksi antar sesama ibu hamil, sehingga sesama ibu hamil 
tersebut akan berbagi pengalaman pengetahuan yang berkaitan dengan kehamilan, persalinan, nifas, KB pasca salin, dan perawatan bayi (Depkes RI, 2009)

Kelas ibu hamil di laksanakan pada setiap tingkat desa, di wilayah Puskesmas Plupuh I yang membawai sekitar 10 desa telah mengadakan kegiatan kelas ibu hamil sejak tahun 2012, kegiatan ini dilaksanakan di setiap desa yang dikelola oleh bidan desa. Berdasarkan uraian kegiatan kelas ibu hamil tersebut peneliti tertarik untuk mengadakan pengamatan langsung dalam kegiatan pelaksanaan kelas ibu hamil di Puskesmas Plupuh I Sragen.

\section{METODE}

Desain penelitian ini adalah Studi Lapangan (Field Research) adalah pengumpulan data secara langsung ke lapangan. Penelitian jenis ini juga dikenal dengan penlitian survey deskriptif(Agung, 2011).Tehnik pengumpulan data dalam penelitian ini adalahObservasi langsung saat kegiatan pelaksanaan kelas ibu hamil, Interview pada bidan pelaksana dan perwakilan peserta kelas ibu hamil, Studi dokumen.

\section{HASIL DAN PEMBAHASAN}

\section{PELAKSANAAN KELAS IBU HAMIL}

Hasil penelitian dengan judul Studi Lapangan Kegiatan Kelas Ibu Hamil di Puskesmas Plupuh I, dengan nara sumber bidan coordinator Puskesmas Plupuh I.

1. Dasar pelaksanaan kelas ibu hamil di Puskesmas Plupuh I.

Pelaksanaan kegiatan kelas ibu hamil dilaksanakan berdasar surat tugas dari kepala puskesmas bulan September tahun 2013.

2. Mulai kapan dilaksanakan kegiatan kelas ibu hamil di Puskesmas Plupuh I

Kelas ibu dilaksanakan mulai bulan Januari tahun 2014.

3. Sumber dana:

Sumber dana untuk kegiatan kelas ibu hamil bersal dari dana Biaya Operasional Kabupaten APBD non fisik.

Dana tersebut digunakan untuk pengadaan konsumsi yang biasanya diwujudkan dalam bentuk makan siang dan snack untuk peserta kelas ibu hamil.

4. Yang terlibat dalam pelaksanaan kegiatan kelas ibu hamil

Dalam pelaksanaan kelas ibu hamil melibatkan beberapa orang, pada awal pelaksanaan yang terlibat adalah kepala 
Puskesmas, bidan coordinator KIA, Bidan desa, perangkat desa, kader kesehatan, dan pengurus PKK. Selanjutnya dalam pelaksanaan kelas ibu hamil yang terlibat adalah kepala puskesmas sebagai penanggungjawab kegiatan, bidan coordinator sebagai pelaksana kegiatan, dan bidan desa sebagai pelaksana kegiatan dan sebagai pemegang wilayah.

5. Pelaksanaan kegiatan.

Pelaksanaan kegiatan diawalai dari pendataan peserta, yaitu data diperoleh dari bidan desa. Kegiatan ini diadakan setiap satu bulan sekali.Kegiatan kelas ibu hamil di Puskesmas Plupuh I dilaksanakan pada setiap wilayah desa, yang biasanya bertempat di Poli Klinik Desa.Peserta yang terdiri dari ibu hamil dari berbagai umur kehamilan setiap bulan rutin diundang oleh bidan desa melalui kader kesehatan untuk mengikuti kegiatan kelas ibu hamil di wilayah desa masing-masing.

Rata-rata jumlah peserta kelas ibu hamil yang tersebar di 8 desa terdiri dari 15-20 ibu hamil, namun ada 1 desa yang jumlah ibu hamilnya mencapai 50 orang. Pada pelaksanaannya ibu hamil ini dibagi menjadi beberpa kelompok dimana rata-rata 10 orang per kelompok, tetapi jika jumlah ibu hamilnya hanya kurang dari 15 maka hanya dijadikan 1 kelompok.Dasar pengelompokan kelas ibu hamil sebenarnya berdasar pada umur kehamilan.

Untuk jadwal pertemuan/kegiatan, jadwal tahunan dibuat oleh pihak puskesmas, dan untuk jadwal bulanan dibuat berdasar kesepakan antara pihak desa dan puskesmas. Hal ini dilakukan karena untuk menghindari benturan kegiatan lain di desa dan puskesmas. Dalam setiap pelaksanaan kelas ibu hamil pihak puskesmas selalu hadir untuk memantau kegiatan dan memberikan materi.

Materi yang diberikan dalam kegiatan kelas ibu hamil sesuai dengan kebutuhan sebagian besar permasalahan ibu hamil. Materi yang disampaikan mengacu pada materi buku KIA.selain materi yang berupa pengetahuan, peserta juga diberikan materi senam hamil.Untuk pelaksanaan senam hamil ditujukan pada ibu hamil dengan umur kehamilan 5 bulan keatas.Pelaksanaan senam hamil tidak bersamaan dengan kegiatan kelas ibu hamil. 
Untuk mengetahui kemampuan ibu hamil dalam menerima materi, dilakukan kegiatan evaluasi pre test dan post test dimana soal mengacu pada materi yang diasampaikan. Selain materi yang diberikan dengan cara ceramah dan diskusi, dalam kegiatan kelas ibu hamil ini juga dilakukan pemeriksaan timbang berat badan dan tensi. Selain itu juga dikaji terutama keluhan yang dirasakan oleh ibu hamil saat itu.

6. Bagaimana dan siapa yang mengadakan sarana dan prasarana.

Sarana dan prasarana untuk kegiatan kelas ibu hamil pihak puskesmas berkoordinasi dengan pihak pemerintah desa dan bidan desa. Misalnya untuk menetukan tempat apabila PKD tidak memadai, biasanya desa mencarikan tempat lain, seperti di aula kantor desa atau di rumah penduduk yang temapatnya memadai dan mengijinkan untuk ditempati. Wilayah Puskesmas Plupuh I berada di daerah pedesaan yang pada umumnya rumah penduduk sangat luas, sehingga tidak mengalami kesulitan dalam mencari tempat kegiatan kelas ibu hamil yang mampu menanmpung ibu hamil dengan jumlah banyak. Sarana yang lain seperti tensi dan timbangan oleh bidan desa masing-masing. Untuk alat tulis masing-masing ibu hamil membawa sendiri-sendiri.

\section{Bagaimana cara mengevaluasi kegiatan}

Untuk mengevaluasi peserta dilakukan pre test dan post test setiap kali pelaksanaan kelas ibu hamil. Sedangkan untuk evaluasi kegiatan secara keseluruhan dilakukan oleh pihak puskesmas, bidan desa, dan pemerintah desa setempat. Evaluasi ini meliputi keatifan peserta, tempat kegiatan, dan proses pelaksanaan.

8. Apakah ada hambatan dalam pelaksanaan Hambatan dalam kegiatan kelas ibu hamil muncul pada bulan Januari sampai dengan bulan Maret. Pada bulan tersebut anggaran biaya untuk kegiatan kelas ibu hamil belum turun. Anggaran atau biaya ini digunakan untuk pengadaan konsumsi (snack dan makan siang).

9. Bagaimana cara menangani hambatan/ kendala tersebut

Untuk mengatasi masalah tersebut, pihak puskesmas memberikan dana talangan. Dana talangan ini hanya cukup untuk mengadakan snack saja.

\section{Laporan kegiatan kelas ibu hamil}

Laporan kegiatan dibuat rutun setiap bulan setelah pelaksanaan kegiatan kelas ibu hamil. Laporan dibuat oleh bidan desa 
dan dilaporkan kepada bidan coordinator/ bidan puskesmas. Isi laporan berupa berita acara/laporan kegiatan, daftar hadir peserta, arsip undangan kegiatan pada ibu hamil, surat tugas, dokumen foto kegiatan, dokumen laporan hasilkegiatan dan pemeriksaan.

Hasil pengamatan penulis saat kegiatan kelas ibu hamil di Puskesmas Plupuh I pada tanggal 4 Mei 2018 dapat dipaparkan sebagai berikut; Kelas ibu hamil adalah suatu aktifitas kelompok yang beranggotakan ibu-ibu hamil umur kehamilan 20-32 minggu, dengan didampingi satu atau beberapa fasilitator tenaga kesehatan seperti bidan atau dokter.Tujuan dari kelas ibu hamil adalah meningkatkan pengetahuan tentang perawatan kehamilan, persalinan, dan nifas.

Kegiatan kelas ibu hamil dilaksanakan di Desa Sambirejo pada tanggal 4 Mei 2018 jam 10.00 WIB sampai dengan 12.00 WIB bertempat di rumah penduduk, dengan luas ruangan sekitar 10mx10m. Kegiatan ini diikuti oleh 26 ibu hamil, 2 bidan Desa Sambirejo, dan petugas dari puskesmas yaitu bidan coordinator KIA.

Hampir semua peserta datang sendiri ke tempat kegiatan, tapi ada $1 \mathrm{ibu}$ hamil yang harus dijemput oleh kader karena tempat ibu hamil agak jauh dan tidak ada transportasi atau tidak ada yang mengantar.Setiap ibu yang datang sebelum duduk masing-masing menimbang BB. Sambil menunggu peserta yang lain bidan desa melakukan pemeriksaan tekanan darah dan menanyakan keluhan dari setiap ibu hamil dan kemudian mencatat dalam sebuah buku hasil pemeriksaan. Setelah peserta diperkirakan telah datang semua, kegiatan dimulai dengan susunan pembukaan, dan penyampaian tujuan kegitan, serta materi yang akan diberikan saat itu. Materi disampaikan oleh bidan Puskesmas dengan materi tanda bahaya kehamilan. Untuk kegiatan evaluasi dilakukan dengan tanya jawab sebelum dan sesudah penyampaian materi.

Pada kegiatan kelas ibu hamil tersebut dihadiri oleh petugas puskesmas yaitu Ibu Kasmawati, AmKeb selaku bidan coordinator dan dua bidan desa, dan dua orang kader kesehatan.

Pada kesempatan tersebut bidan coordinator mengisi kegiatan kelas ibu hamil dengan memberikan pendidikan kesehatan pada peserta dengan topic materi "Tanda Bahaya Kehamilan”. Kegiatan ini sesuai dengan tujuan pelaksanaan kelas ibu hamil 
(Depkes RI,2009), bahwa dalam pelaksanaan kelas ibu hamil petugas kesehatan termasuk bidan merupakan fasilitator atau nara sumber, dimana petugas kesehatan merupakan nara sumber untuk menyampaikan materi. Tenaga kesehatan terutama bidan mempunyai keahliahan yang sesuai dengan kebutuhan peserta kelas ibu hamil, sehingga hal ini sangat mendukung untuk mencapai tujuan kelas ibu hamil yaitu meningkatkan pengetahuan ibu hamil, yang diharapkan dapat merubah sikap dan perilaku ibu yang masih kurang dalam perawatan kehamilan.

Dari hasil wawancara pada bidan coordinator, kegiatan kelas ibu hamil rutin dilaksanakan setiap bulan sekali.Informasi ini diperkuat dari hasil wawancara dengan beberapa peserta, bahwa kegiatan kelas ibu hamil dilaksanakan rutin setiap bulan.

Dalam pelaksanaan kegiatan kelas ibu hamil, tidak ada pengelompokan kelas, semua peserta jadi satu dan mendapat materi yang sama.

Berdasarkan hasil wawancara dan pengamatan penulis pada kegiatan pelaksanaan kelas ibu hamil dapat disajikan pembahasan sebagai berikut:

Kelas ibu hamil yang dilaksanakan di Puskesmas Plupuh I cukup baik, dimana puskesmas telah melaksanakan kegiatan kelas ibu hamil secara rutin setiap bulan, dengan peserta sesuai jumlah sasaran ibu hamil yang ada di wilayah tersebut. Hal ini sesuai dengan buku panduan Pedoman Pelaksanaan Kelas Ibu Hamil (Depkes RI 2009) dan teori dalam bukunya Pudiastuti, 2011 yaitu bahwa kelas ibu hamil dilakukan rutin setiap bulan dengan sasaran seluruh ibu hamil diwilayah masingmasing hal ini merupakan salah satu upaya pemerintah pusat untuk menurunkan AKI dengan suatu pendekatan kepada ibu hamil untuk meningkatkan kualitas kesehatan ibu dan anak.

Kegiatan kelas ibu hamil di Puskesmas Plupuh I merupakan sarana untuk belajar kelompok tentang kesehatan bagi ibu hamil untuk memahami masalah kesehatanibu hamil dan pembekalan agar ibu hamil mampu memecahkan permasalahannya.Tujuan umum dari kelas ibu hamil adalah dipahaminya dan terlaksananya metode pembelajaran kelas ibu hamil berbasis pada kajian buku KIA. Secara khusus tujuan kelas ibu hamil adalah tercapianya pemahaman dan identifikasi kesehatan diri ibu hamil beserta solusinya, pemahaman isi materi buku KIA yang dimiliki oleh setiap ibu hamil, dan memberikan dorongan motivasi kepada ibu hamil supaya 
sukses dalam menghadapi permasalahan yang berdampak pada permasalahan sekitar ibu dan bayi.

Kegiatan dan tujuan kelas ibu hamil di Puskesmas Plupuh I selain telah sesuai dengan uraian yang tertuang dalam buku pedoman kelas ibu hamil Dep.Kes 2009. Pelaksanaan kelas ibu hamil di Puskesmas Plupuh dapat dilaksankan secara rutin dan di hadiri oleh bidan senior/koordinator puskesmas sebagai tenaga professional untuk menyampaikan materi seputar KIA. Hal tersebut sesuai dengan buku Pudiastuti 2011, yang menyatakan bahwa keuntungan kelas ibu hamil adalah penyampaian materi diberikan oleh tenaga professional sehingga materi lebih komprehensif dan efektif. Selain itu juga dapat terjadi interkasi yang berkesinambungan secara rutin antara petugas kesehatan dengan ibu hamil karena kelas ibu hamil dilaksanakan secara berkala dan berkesimbungan.Untuk pemahaman materi bidan melakukan evaluasi pada ibu hamil dalam setiap menyampaikan materi, sehingga diharapkan dapat meningkatkan kualitas sistim pembelajaran.

Materi yang disampaikan dalam kelas ibu hamil menurut bidan adalah sesuai dengan materi yang ada dibuku KIA, dimana masingmasing ibu hamil telah mempunyai buku tersebut.Namun selain materi yang ada dalam buku KIA, bidan juga menjelaskan materi sesuai kondisi yang dialami oleh ibu hamil dalam kelas tersebut.Untuk evaluasi materi dilakukan sebelum dan setelah selesai pemaparan materi.Selain dari evaluasi dalam setiap pertemuan tersebut juga dibuka kesempatan diskusi baik dari materi yang disampaikan atau bisa dari permasalahan per individu.Hal ini sesuai dengan Pedoman Panduan Kelas ibu hamil 2009 yang menyebutkan bahwa kurikulum dalam kelas ibu hamil adalah buku KIA yang didalamnya berisi tentang perawatan kehamilan, persalinan, nifas, KB, kesehatan anak yang meliputi; BBL, Neonatus, Imunisasi, Balita, Gizi bayi dan balita, KMS dan SDIDTK (Buku KIA, Kemenkes RI 2007)

Sasaran kelas ibu hamil.dari hasil pengamatan diperoleh peserta kelas ibu hamil tidak memperhatikan umur kehamilan, dan tidak dikelompokan, serta jumlah yang banyak lebih dari 10 orang. Hal ini kurang sesuai dengan buku panduan kelas ibu hamil yang diterbitkan oleh Depkes RI 2009, dimana dituliskan bahwa peserta kelas ibu hamil sebaiknya adalah ibu hamil dengan umur kehamilan $20 \mathrm{~s} / \mathrm{d} 32$ minggu, karena pada 
ISSN: 1858-3385, EISSN: 2549-7006

GASTER Vol. 17 No. 2 Agustus 2019

umur kehamilan ini kondisi ibu sudah kuat, tidak takut terjadi keguguran, efektif untuk melakukan senam hamil. Dalam buku panduan tersebut juga dijelaskan bahwa jumlah peserta ibu hamil maksimal dalam setiap kelompok sebanyak 10 orang.Menurut bidan yang mengelola kelas ibu hamil, hal ini disebakan karena keterbatasan tenaga dan waktu. Selain itu banyak kegiatan lain yang menjadi tugas yang harus diemban oleh bidan.

\section{SIMPULAN}

Pelaksanaan kelas ibu hamil di Puskesmas Plupuh I sudah cukup baik, semua jajaran dari kepala puskesmas sampai masyarakat ikut terlibat dan dapat dilaksanakan rutin setiap bulan, sasaran ibu hamil sebagian besar bisa rutin datang, adanya pre test dan post test materi sebagai evaluasi kualitas pemahaman pengetahuan oleh peserta.

\section{DAFTAR PUSTAKA}

Agung (2011).Penjelasan Penelitian Studi Lapangan.http://teori-ilmupemerintahan.blogspot. co.id/2011/06/penjelasan-studi-lapangan-penelitian.html

Depkes RI (2009). Pedoman Pelaksanaan Kelas Ibu Hamil. Depkes RI: Jakarta

Dirjen Bina Kesehatan Masyarakat (2009). Pedoman Pemantauan Wilayah Setempat Kesehatan Ibu dan Anak. Depkes RI: Jakarta

Kemenkes RI( 2007)Buku KIA Kemenkes RI: Jakarta

Pudiastuti, R.D. (2011) Kebidanan Komunitas. Nuha Medika: Yogyakarta 